\title{
THE GENETICS OF ARTEMIA SALINA. II. WHITE EYE, A SEX-LINKED MUTATION ${ }^{1}$

\author{
SARANE THOMPSON BOWEN \\ Department of Biology, San Francisco State College, \\ San Francisco 27, California
}

Although there have been many cytological studies of sex determination in the Crustacea (reviewed by Niiyama, 1959), this paper will describe the first genetic study of crustacean sex determination. It will be shown that the female is the heterogametic sex in the brine shrimp. Sex differentiation in Artemia has been discussed by Bowen and Hanson (1962).

The culture medium and the genetic techniques used in the following experiments were described in the first paper in this series (Bowen, 1962).

The author would like to thank Miss Jean Hanson, Mr. Dan Straus, and Mr. H. Stuart Williamson for their assistance throughout this study.

\section{Materials}

Origin of stock \#5

In all the races of Artemia, the wild-type eye is black. The recessive autosomal gene, $r$, for red eyes arose as a spontaneous mutation in the Utah race. It was described in the first paper in this series. A second autosomal gene, $c$, which determines "crinkle eyes," has not been described previously. This mutation arose spontaneously in the California race (San Francisco Bay) and was discovered by Miss Jean Hanson in 1960. At the age of three to five weeks, shrimp of the $c c$ genotype develop an extra patch of pigment cells on the eyestalk. The two mutations have been combined in a single line, designated as stock \# 5 in our laboratory. Young shrimp in this $r r c c$ stock have red eyes. At sexual maturity their eyes turn brown or black. At the age of five weeks the pigment in the normal eye field is black, but the pigment in the "crinkles" patch on the eyestalk is still red.

\section{Origin of the white eye mutation}

A wild-type male from a cyst collected at Great Salt Lake, Utah, was mated to a female of the \#5 stock. An $F_{1}$ male with the $\operatorname{Rr} C c$ genotype was backcrossed to another \# 5 stock female. In this progeny the author found one white-eyed male in December of 1961.

1 This research was supported by a grant from the National Science Foundation (NSF G-23863). 


\section{RESUlts}

The terms pigmented or wild-type phenotype are used below to designate nonwhite-eyed shrimp. Because the first white-eyed male had the genotype $R r$, some of the pigmented shrimp were red-eyed and some were black-eyed in Experiments $\mathrm{A}, \mathrm{B}$, and $\mathrm{C}$.

\section{Experiment $A$}

The first white male was mated to a female from the \#5 stock. This mating is represented as Generation $\mathrm{I}$ in Figure 1. Three broods of pigmented $\mathrm{F}_{1}$ nauplii were produced: a total of 14 males and 19 females lived to maturity. The $\mathrm{F}_{1}$ shrimps were mated to each other to produce an $\mathrm{F}_{2}$ which consisted of 14 white males, 16 pigmented males, and 32 pigmented females (shown in Generation III of the pedigree). In this first experiment, the mode of inheritance of white eye in Artemia resembled that of white eye in Drosophila.
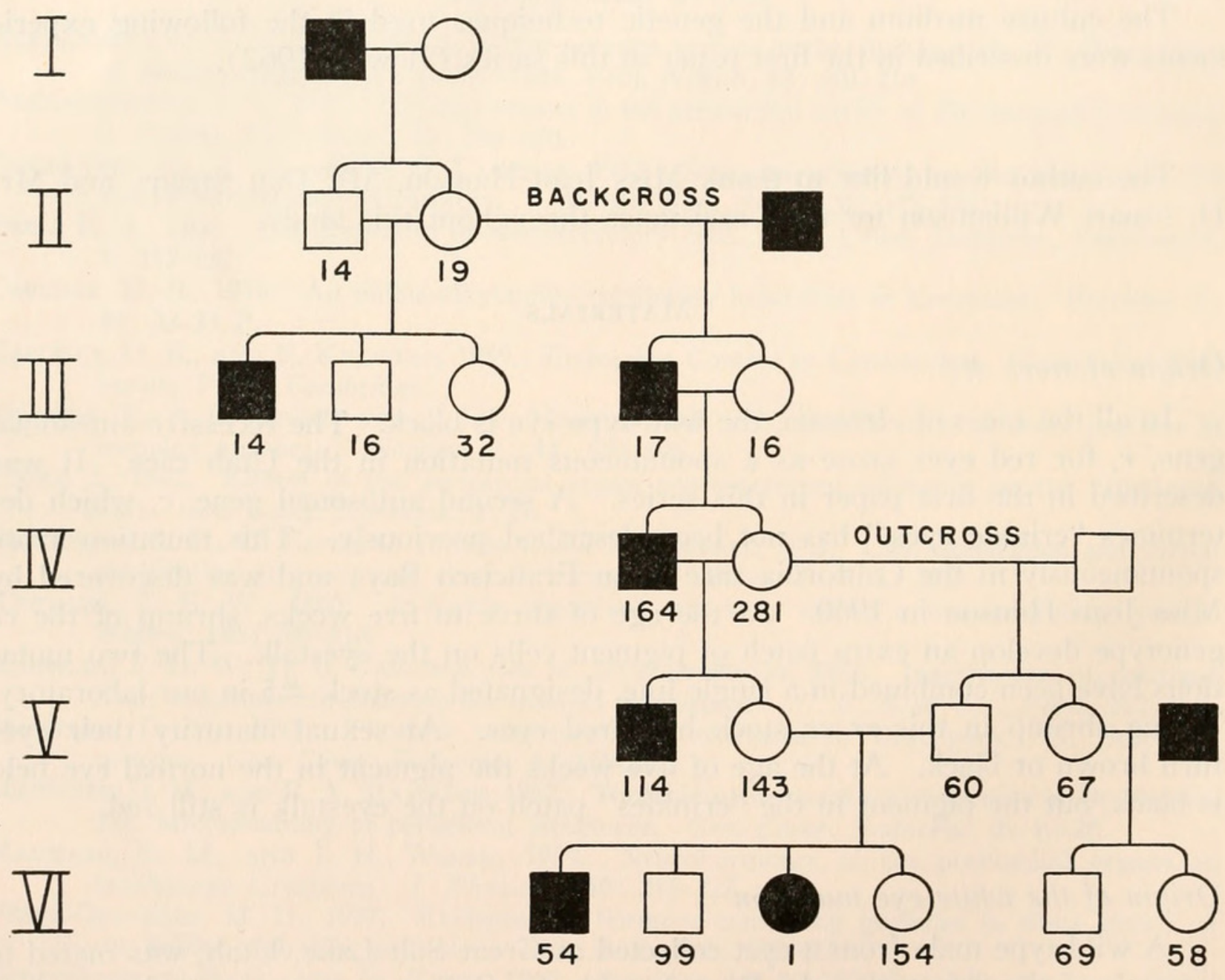

FIGURE 1. Pedigree showing the distribution of white eye in the first six generations. Conventional genetic notation is used: solid symbols indicate shrimps with mutant phenotype; open symbols indicate shrimps with wild-type phenotype (pigmented eyes). Squares represent males; circles represent females. The number written under each symbol indicates the number of progeny in that class. 


\section{Experiment $B$}

An $F_{1}$ female from Experiment $A$ was backcrossed to the first white male. Surprisingly, the progeny consisted of 17 white males and 16 pigmented females (shown in Generation III of the pedigree in Figure 1). These shrimp were mated inter se and produced 164 white males and 281 pigmented females. These were mated to each other and the progeny consisted of 114 white males and 143 pigmented females. Thus, the mating of a white male to the pigmented daughter of a white male results in a pure-breeding stock of white males and pigmented females. This stock is carried in our laboratory as stock \#9.

\section{Experiment $C$}

Three females from stock \#9 were outcrossed to wild-type males which had hatched from cysts collected in Quemado, New Mexico (U.S.A.). The $F_{1}$ shrimps (shown in Generation $\mathrm{V}$ of the pedigree) were all pigmented: 60 males and 67 females. Six of the $F_{1}$ females were mated to \#9 stock white males, and again the progeny were all pigmented: 69 males and 58 females. Four of the $F_{1}$ males were mated to females from the \#9 stock. These four matings produced 54 white males, 99 pigmented males, 154 pigmented females, and one white female (shown in the sixth generation of the pedigree). This first white female appeared in May of 1962. She was mated to a white brother and produced all white-eyed progeny.

\section{The Hypothesis of Partial Sex Linkage}

The experimental results can be accounted for by the following assumptions: (1) The mutant gene $w$ which determines white eyes is recessive to its wild-type allele $W$. (2) The females are heterogametic. The chromosome constitution of the female will be represented as XY; the males will be XX. (3) The white locus is partially sex-linked. Because it is on the homologous segment of the sex chromosomes, both males and females may be $W W, W w$, or wrw.

The first white female probably arose as the result of a crossover between the white locus and the "sex locus." It is not known whether sex is determined by two alleles at one true sex locus or by several loci on the differential segment of the $\mathrm{X}$ or the $\mathrm{Y}$ chromosome. If there were several loci governing sex determination, the "sex locus" would be designated as the place where the differential segment of a sex chromosome joins the homologous segment (Fig. 2). Both concepts of a sex locus would be in accord with the experimental results.

The cytological studies of Artemia (reviewed by Barigozzi, 1957) have not revealed the presence of a pair of chromosomes of unequal length. For this reason the $\mathrm{X}$ and $\mathrm{Y}$ chromosomes in Figure 2 are shown to be the same length. The length of the differential segment in relation to the homologous segment is an arbitrary choice. Only one differential segment is shown on each sex chromosome although in many species two such segments have been found (reviewed by Darlington, 1958).

Partial sex-linkage has been reported in three genera of viviparous killifishes (family Poeciliidae): in Aplocheilus latipes (Aida, 1921), in the guppy, Lebistes reticulatus (Winge and Ditlevsen, 1947) and in the platyfish, Xiphophorus (Platy- 


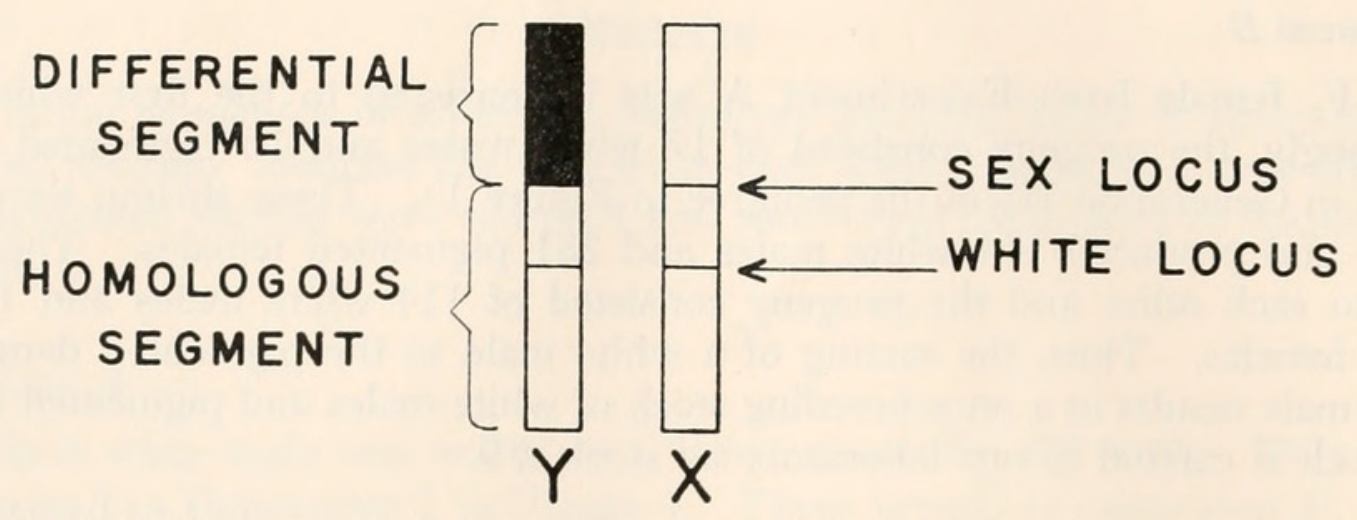

Figure 2. Diagram of the sex chromosomes of Artemia. Crossing over may occur between the white locus and the sex locus.

poecilus) maculatus (Gordon, 1937, 1947 ; reviewed by Bellamy and Queal, 1950). Crossover of a gene from the $\mathrm{X}$ to the $\mathrm{Y}$ chromosome has also been reported at the bobbed locus of Drosophila melanogaster (Stern, 1929; Neuhaus, 1937). A1though many characteristics in the human have been reported to be partially sexlinked, Morton (1957) has found that in every instance the data fell short of statistical significance.

\section{Explanation of the Experimental Results}

In Figure 3 the hypothesis of partial sex-linkage is applied to two experiments. On the left is a pedigree which describes Experiment A. If a white male is mated
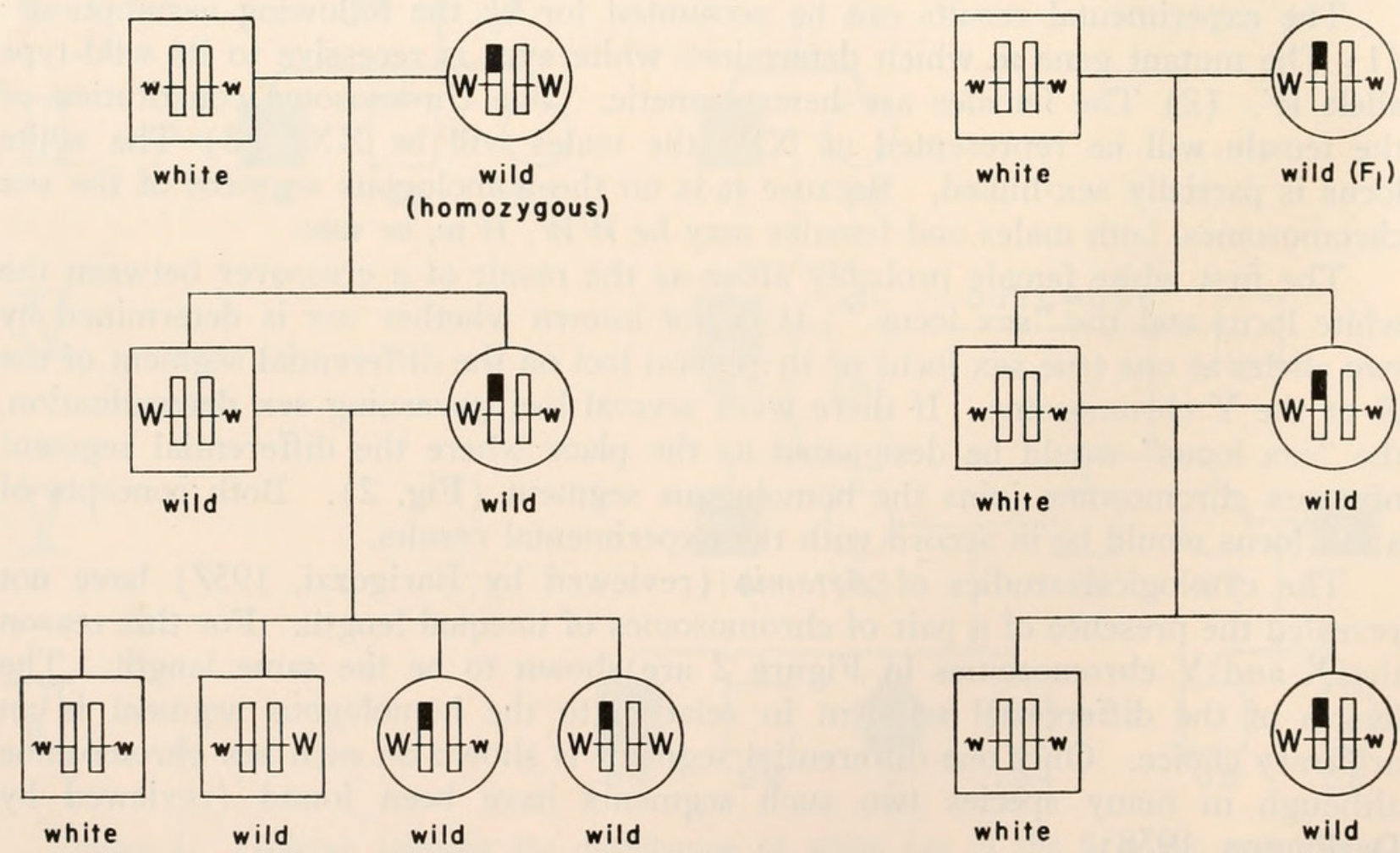

Figure 3. Sex-linked inheritance in Artemia. Squares represent males; circles represent females. The phenotype of each class is written beneath the symbol. The X and Y chromosomes are shown as in Figure 2. Crossing over between the $\mathrm{X}$ and $\mathrm{Y}$ does not occur in these two experiments. 
to a homozygous wild-type (pigmented) female, all the $\mathrm{F}_{1}$ progeny will be wildtype. If the $\mathrm{F}_{1}$ shrimps are mated inter se, the $\mathrm{F}_{2}$ phenotypic ratio would be: $1 / 4$ white males: $1 / 4$ wild-type males: $1 / 2$ wild-type females. The observed ratio was $14: 16: 32$.

On the right side of Figure 3 is a pedigree which explains the data in Experiment B. If a white male is mated to the heterozygous daughter of a white male, a pure-breeding stock of white males and phenotypically wild-type females will be established. That there were fewer males than females classified in Experiment B is probably due to the lower viability of the white phenotype (discussed below).

Partial sex-linkage was proposed as the mode of inheritance of white eye before the fourth generation was classified. At that time it was predicted that a whiteeyed female would be produced as the result of crossing over. Experiment $\mathrm{C}$ was designed to test the hypothesis of partial sex-linkage; the results are in accord with the hypothesis.

\section{Summary of Genetic Data}

The data from Experiments A, B, and C, and from additional matings made in the summer of 1962 are combined in Table I. The number of broods may exceed the number of matings because some matings produced more than one brood. The viability of the white phenotype calculated from the progeny of matings of $\mathrm{X}^{\mathrm{w}} \mathrm{Y}^{\mathrm{w}}$ females $\times X^{w} X^{w}$ males is $623 / 877$ or 0.71 . Good agreement is found when the viability is calculated from the all-male progeny of matings of $X^{w} Y^{w}$ females $\times \mathrm{X}^{\mathrm{w}} \mathrm{X}^{\mathrm{w}}$ males: $99 / 152$ or 0.65 . The author is unable to explain the significant deviation from the expected ratio in the progeny of matings of $\mathrm{X}^{\mathrm{w}} \mathrm{Y}^{\mathrm{w}}$ females $\times \mathrm{X}^{\mathrm{w}} \mathrm{X}^{\mathrm{w}}$ males. One would expect the ratio of pigmented females to pigmented males to be 2 . The observed ratio is $247 / 152$ or 1.6.

The $\mathrm{X}$ and $\mathrm{Y}$ chromosomes carried by stock \#9 are of special interest. The $\mathrm{X}$ chromosome is marked by the mutant gene $w$ and was carried by the first whiteeyed shrimp (an $\mathrm{X}^{\mathrm{w}} \mathrm{X}^{\mathrm{w}}$ male). The mutant gene arose spontaneously in the $\mathrm{X}$ chromosome which evidently came from the \#5 stock. The Y carries the wild

TABLE I

Segregation of the gene w. (In the genotype of the female parent, the gene on the $\mathrm{Y}$ chromosome is underlined)

\begin{tabular}{|c|c|c|c|c|c|c|c|}
\hline \multirow{2}{*}{$\begin{array}{c}\text { Number of } \\
\text { matings }\end{array}$} & \multirow{2}{*}{$\begin{array}{c}\text { Number of } \\
\text { broods }\end{array}$} & \multirow{2}{*}{$\begin{array}{l}\text { Mating } \\
\text { female } \times \text { male } \\
(\mathrm{XY}) \quad(\mathrm{XX})\end{array}$} & \multicolumn{5}{|c|}{ Number of offspring } \\
\hline & & & $\begin{array}{l}\text { White } \\
\text { male }\end{array}$ & $\begin{array}{l}\text { White } \\
\text { female }\end{array}$ & $\begin{array}{l}\text { Pigmented } \\
\text { male }\end{array}$ & $\begin{array}{l}\text { Pigmented } \\
\text { female }\end{array}$ & Tota \\
\hline 25 & 32 & $W W \times w w$ & 0 & 0 & 360 & 362 & 722 \\
\hline 61 & 82 & $w \bar{W} \times w w$ & 623 & 0 & 0 & 877 & 1500 \\
\hline 3 & 4 & $w \bar{W} \times W W$ & 0 & 0 & 60 & 67 & 127 \\
\hline 14 & 21 & $w W \times W w$ & 99 & 1 & 152 & 247 & 499 \\
\hline 23 & 31 & $w w \times w w$ & 166 & 174 & 0 & 0 & 340 \\
\hline
\end{tabular}


allele and was present in the \#5 female ( $\left.\mathrm{X}^{\mathrm{w}} \mathrm{Y}^{\mathrm{w}}\right)$ to which this male was mated in Generation I. Crossing over between this $\mathrm{X}^{\mathrm{w}}$ chromosome and this $\mathrm{Y}^{\mathrm{w}}$ chromosome is rare. For example from the $\# 9$ stock matings $\left(\mathrm{X}^{\mathrm{w}} \mathrm{Y}^{\mathrm{w}}\right.$ females $\times \mathrm{X}^{\mathrm{w}} \mathrm{X}^{\mathrm{w}}$ males), a total of 1500 progeny consisted of white males and pigmented females. That is, no crossovers were detected among the 1500 female gametes tested. However, one recombinant was found among the 499 offspring of matings of \#9 stock females to $\mathrm{X}^{\mathrm{w}} \mathrm{X}^{\mathrm{w}}$ males (shown in the fourth line in Table I). Since only onefourth of the recombinant progeny of such matings can be detected, the crossover rate here is $4 / 499$ or $1 / 125$. The crossover frequency calculated from all the data from \#9 females is $1 /(125+1500)$ which is $1 / 1625$ or $0.06 \%$.

The racial origin of these two chromosomes is unknown because they originated from the \#5 stock which is derived from both the Utah and California races. In a later paper it will be shown that when a female is carrying the same $\mathrm{X}^{\mathrm{w}}$ chromosome and a $\mathrm{Y}^{\mathrm{w}}$ from another source, the frequency of crossing over may be as high as $9 \%$. Evidently a crossover suppressor mechanism is present in stock \#9.

\section{SumMary}

1. This paper describes the first sex-linked gene discovered among the Crustacea. The experimental results can be accounted for by the following hypotheses: (1) the mutant gene $w$, which determines white eyes, is recessive to its wild allele $W$. (2) Female brine shrimp are heterogametic. The chromosome constitution of the female will be represented as XY; the males are XX. (3) The white locus is partially sex-linked. Because it lies on the homologous segments of the sex chromosomes, both males and females may have the genotype of $W W, W w$, or wre.

2. In matings of $W w$ females to ww males, crossing over between the white locus and the sex locus may be detected. In the \#9 stock, females have the genotype $\mathrm{X}^{\mathrm{w}} \mathrm{Y}^{\mathrm{w}}$ and the frequency of crossing over is low $(1 / 1625$ or $0.06 \%)$. This results in a "mother-to-daughter" inheritance of the $W$ gene in the \#9 stock.

\section{LITERATURE CITED}

AIdA, T., 1921. On the inheritance of color in a fresh-water fish Aplocheilus latipes Temmick and Schlegel, with special reference to sex-linked inheritance. Genetics, 6: 554-573.

BARIgOzzI, C., 1957. Differénciation des génotypes et distribution géographique d'Artemia salina Leach: données et problèmes. Année Biol., 33: 241-250.

Bellamy, A. W., and M. L. Queal, 1950. Heterosomal inheritance and sex determination in Platypoecilus maculatus. Genetics, 36: 93-107.

Bowen, S. T., 1962. The genetics of Artemia salina. I. The reproductive cycle. Biol. Bull., 122: $25-32$.

Bowen, S. T., and J. Hanson, 1962. A gynandromorph of the brine shrimp, Artemia salina. Genetics, 47: 277-280.

Darlington, C. D., 1958. The Evolution of Genetic Systems. Basic Books, Inc., New York.

Gordon, M., 1937. Genetics of Platypoecilus. III. Inheritance of sex and crossing over of the sex chromosomes in the Platyfish. Genetics, 22: 376-392.

Gordon, M., 1947. Genetics of Platypoecilus maculatus. IV. The sex determining mechanism in two wild populations of the Mexican platyfish. Genetics, 32: 8-17.

Morton, N. E., 1957. Further scoring types in sequential linkage tests, with a critical review of autosomal and partial sex linkage in man. Amer. J. Hum. Genet., 9: 55-75. 
Neuhaus, M. H., 1937. Additional data on crossing over between X and Y chromosomes in Drosophila melanogaster. Genetics, 22: 333-339.

Niryama, H., 1959. A comparative study of the chromosomes in decapods, isopods and amphipods, with some remarks on cytotaxonomy and sex-determination in the Crustacea. Memoirs of the Faculty of Fisheries, (Hokkaido University), 7: 1-60.

Stern, C., 1929. Untersuchungen über Aberrationen des Y-chromosoms von Drosophila melanogaster. Zeitschr. induktive Abstammungs- und Vererbungslehre, 51: 253-353.

Winge, O., And E. Ditlevsen, 1947. Colour inheritance and sex determination in Lebistes. Heredity, 1: 67-83. 


\section{$2 \mathrm{BHL}$ Biodiversity Heritage Library}

Bowen, Sarane Thompson. 1963. "THE GENETICS OF ARTEMIA SALINA. II. WHITE EYE, A SEX-LINKED MUTATION." The Biological bulletin 124, 17-23. https://doi.org/10.2307/1539564.

View This Item Online: https://www.biodiversitylibrary.org/item/17150

DOI: https://doi.org/10.2307/1539564

Permalink: https://www.biodiversitylibrary.org/partpdf/5215

\section{Holding Institution}

MBLWHOI Library

\section{Sponsored by}

MBLWHOI Library

\section{Copyright \& Reuse}

Copyright Status: In copyright. Digitized with the permission of the rights holder.

License: http://creativecommons.org/licenses/by-nc-sa/3.0/

Rights: https://biodiversitylibrary.org/permissions

This document was created from content at the Biodiversity Heritage Library, the world's largest open access digital library for biodiversity literature and archives. Visit BHL at https://www.biodiversitylibrary.org. 